\title{
HERMENÊUTICA FILOSÓFICA E DIREITO: CONTRIBUIÇÕES TEÓRICAS
}

\author{
PHILOSOPHICAL HERMENEUTICS AND LAW: THEORETICAL CONTRIBUTIONS
}

Luíza Kitzmann Krug*

Submissão: 10/06/2013

Aceito para Publicação: 14/08/2013

\begin{abstract}
Sumário: INTRODUÇÃO. 1. A APLICAÇÃO DA LEI (INTERPRETAÇÃO) E VIRAGEM LINGUÍSTICA. 2. AS CONTRIBUIÇÕES DE HEIDEGGER E GADAMER. 3. HERMENÊUTICA E JURISDIÇÃO CONSTITUCIONAL. CONSIDERAÇÕES FINAIS. REFERÊNCIAS.
\end{abstract}

Resumo: Este artigo objetiva explorar as contribuições teóricas da Hermenêutica Filosófica ao Direito brasileiro. A discussão é contextualizada através da abordagem da superação da metafísica clássica pelo giro ontológico-linguístico. Realiza-se a análise da crise de paradigmas de dupla-face vigente da dogmática jurídica brasileira, representada pela crise do paradigma liberal-individualista-normativista e do paradigma da filosofia da consciência. Com base nos filósofos Martin Heidegger e Hans-Georg Gadamer, realiza-se um estudo da questão interpretação do Direito por meio da Hermenêutica Filosófica, trabalhando-se os conceitos de pré-compreensão, applicatio e tradição. Demonstra-se de que maneira a Hermenêutica Filosófica é uma alternativa viável de interpretação do Direito brasileiro, especialmente no que tange à jurisdição constitucional. Ao final, realiza-se a análise de julgados para verificar a extensão da inserção das teses abordadas no âmbito do Supremo Tribunal Federal.

Palavras-chave: Hermenêutica Filosófica; Metafísica; Giro ontológico-linguístico; Jurisdição Constitucional; Supremo Tribunal Federal brasileiro.

Abstract: This article aims to explore the theoretical contributions of Philosophical Hermeneutics to Brazilian Law. The debate is contextualized through the approach of the overcoming of classical metaphysics by the linguistic-ontological turn. It is carried out the analysis of the double-front paradigm crises that is taking place in the Brazilian legal dogmatic, represented by the crises of the liberal-individualistic-normative paradigm and of the philosophy of conscience paradigm. Based on the works of the philosophers Martin Heidegger and Hans-Georg Gadamer, it is carried out a study of the matter of interpretation of Law through the Philosophical Hermeneutics, working up the concepts of

\footnotetext{
* Universidade Federal do Rio Grande.
} 
preunderstanding, applicatio and tradition. It is shown in which way the Philosophical Hermeneutics is a viable alternative of interpretation of Brazilian Law, especially in what concerns constitutional jurisdiction. At the end, it is carried out the analysis of legal cases in order to verify the extension of insertion of the approached thesis in the realm of the Brazilian Supreme Court.

Keywords: Philosophical Hermeneutics; Metaphysics; Linguistic-Ontological Turn; Constitutional Jurisdiction; Brazilian Federal Supreme Court.

\section{INTRODUÇÃO}

No meio jurídico, uma constante preocupação é a que concerne à interpretação. Na esteira desta problemática, considerando-se ainda o papel fundamental da Constituição no Direito brasileiro, importa buscar uma maneira de confrontarem-se os dispositivos ordinários com a normativa constitucional que se demonstre adequada ao contexto constitucionalista vigente. Até porque, “uma Constituição nova (...) exige novos modos de análise”1 , ou seja, em tempos de constitucionalismo democrático não se pode admitir que uma decisão que se diga constitucionalmente adequada dependa de juízos pessoais ou subjetivismos morais com pretensão corretiva do Direito. Essa é a finalidade do presente estudo, qual seja apontar um modo que se possa traduzir uma atuação judicial (democrática) dentro do programa constitucional.

Neste intuito, encontra-se inspiração no seguinte questionamento de Streck: "Por que o pensar dos juristas seria diferente do pensar do filósofo? Por que o jurista teria um diferente ‘acesso’ à ‘realidade’?”2. Conclui, ainda, o autor que “nada está a indicar que o direito tenha 'ficado de fora’ ou que possa estar 'blindado' aos influxos dessas verdadeiras revoluções copernicanas que atravessaram a filosofia ao longo de mais de dois mil anos da história ocidental."3

Com este estímulo, adentra-se o âmbito do pensamento filosófico para a busca de uma solução à problemática interpretativa. Destarte, pretende-se demonstrar, através deste trabalho, de que forma a Hermenêutica Filosófica apresenta-se como um caminho a ser seguido pelos juristas na empreitada do processo interpretativo, especialmente no que tange à jurisdição constitucional e à avaliação da constitucionalidade das normas.

\footnotetext{
${ }^{1}$ STRECK, Lenio Luiz. Hermenêutica jurídica e $(m)$ crise: uma exploração hermenêutica do Direito. 10 ed. rev. atual. e ampl. Porto Alegre: Livraria do Advogado Editora, 2011. p. 80.

${ }^{2}$ STRECK, Lenio Luiz. O que é isto - decido conforme minha consciência? 2. ed. rev. e ampl. Porto Alegre: Livraria do Advogado, 2010. p. 10.

${ }^{3}$ STRECK, O que é isto, op. cit., p. 18.
} 
Para tanto, abordar-se-á de início a questão da do giro linguístico-ontológico, passando-se em seguida à exposição do pensamento filosófico de Heidegger e Gadamer. Ao final, é realizada uma breve análise de alguns julgados do Supremo Tribunal Federal para verificar a extensão da inserção das teses ora analisadas no âmbito da corte constitucional brasileira.

\section{A APLICAÇÃO DA LEI (INTERPRETAÇÃO) E VIRAGEM LINGUÍSTICA}

Na sua obra Verdade e Método, o filósofo Hans-Georg Gadamer afirma que aplicar a lei é, necessariamente, um ato interpretativo. O autor rejeita a ideia de que seja possível promulgar uma sentença por um mero ato de subsunção ${ }^{4}$. Na perspectiva de uma Hermenêutica Filosófica, não é admissível que o fato se subsuma à norma de maneira automática. Para o autor, são inseparáveis a compreensão, a interpretação e, por sua vez, a aplicação. ${ }^{5}$ É indispensável, e até mesmo inevitável, a ocorrência do processo interpretativo.

Ocorre que, no meio jurídico, este entendimento não é unânime. Sob outra perspectiva teórica, admite-se a dicotomia subsunção/interpretação, cindindo-se os casos em que ocorre a simples aplicação da lei ao caso em tela (subsunção) daqueles em que é necessária a interpretação dos dispositivos legais aplicáveis. Esta ideia está presente nas teorias de autores como Herbert Hart ${ }^{6}$, Ronald Dworkin ${ }^{7}$ e Robert Alexy $^{8}$, os quais entendem possível a distinção entre casos fáceis (easy cases) e casos difíceis (hard cases).

Nesta perspectiva, denominam-se casos fáceis aqueles nos quais se entende desnecessária a interpretação dos dispositivos normativos envolvidos na sua solução. Isto pressupõe a anterior existência de uma norma que resolva o caso, havendo o encaixe perfeito entre a conduta humana e o texto legal. $\mathrm{O}$ trabalho do julgador seria de tão-somente verificar a existência da norma e sua aplicação ao caso em análise, através da subsunção do fato à norma.

Os casos difíceis, por sua vez, constituem-se em casos nos quais não é observada a existência de norma anterior que se encaixe perfeitamente ao caso. Ou não existem normas

\footnotetext{
${ }^{4}$ GADAMER, Hans-Georg. Verdade e método: traços fundamentais de uma hermenêutica filosófica. Tradução de Flavio Paulo Meurer. Revisão da tradução de Enio Paulo Giachini. 2. ed. Petrópolis: Vozes, 1998. p. 490.

${ }^{5}$ GADAMER, Verdade e Método, op. cit., p. 459.

${ }^{6}$ HART, H. L. A. O conceito de direito. Pós-escrito organizado por Penélope A. Bulloch e Joseph Raz. Tradução de Antônio de Oliveira Sette-Câmara; revisão da tradução de Marcalo Brandão Cipolla; revisão técnica Luiz Virgílio Dalla-Rosa. São Paulo: Editora WMF Martins Fontes, 2009.

${ }^{7}$ DWORKIN, Ronald. Levando os direitos a sério. Tradução de Nelson Boeira 3. ed. São Paulo: Editora WMF Martins Fontes, 2010. passim.

${ }^{8}$ ALEXY, Robert. Teoria dos direitos fundamentais. Tradução de Virgílio Afonso da Silva. São Paulo: Maheiros, 2008. passim.
} 
aplicáveis, ou, existindo, estas estão em conflito, tornando nebulosa a determinação da norma a ser aplicada por subsunção. Neste sentido, é a análise de Dworkin:

O positivismo jurídico fornece uma teoria dos casos difíceis. Quando uma ação judicial específica não pode ser submetida a uma regra de direito clara, estabelecida de antemão por alguma instituição, o juiz tem, segundo tal teoria, o "poder discricionário” para decidir o caso de uma maneira ou de outra. ${ }^{9}$

Também no direito pátrio há autores que defendem a tese de que, na clareza da lei, desnecessária a interpretação, sendo Washington de Barros Monteiro a principal referência nesse sentido. Tal corrente é caracterizada pelo brocardo jurídico lex clara non indiget interpretatione. $^{10}$

Defende-se, a contrario sensu, que o processo interpretativo ocorra em todos os casos, perspectiva também defendida por Francisco Motta, que dispõe:

\footnotetext{
Não nos parece hermeneuticamente correta a distinção entre casos fáceis e casos difíceis que, queiramos ou não, está presente em Dworkin. Um caso é apenas um caso, e será "fácil" ou "difícil" de acordo com o intérprete que com ele se confrontar. Na verdade, um caso "difícil” é apenas um caso não compreendido, até porque quando um caso é corretamente compreendido, a interpretação “desaparece”, não nos perguntamos mais por ela. ${ }^{11}$
}

Isto porque, diante da mudança paradigmática estabelecida pelo giro ontológicolinguístico, o qual veio para superar a metafísica clássica, passou-se a entender que o Direito, assim como o mundo, se dá na e pela linguagem, sendo desta indissociável. Enquanto, na metafísica clássica, acreditava-se que os sentidos estavam contidos nas coisas, ${ }^{12}$ no âmbito do giro superou-se o esquema sujeito-objeto para dar lugar a um esquema sujeito-sujeito. Isto é, passou-se a entender-se que a construção do conhecimento ocorre através do uso da linguagem. Ocorre que, na concepção de Streck, “o campo jurídico brasileiro continua sendo refratário a essa viragem linguística”. ${ }^{13}$

Para o autor, o Direito brasileiro estaria vivendo uma crise paradigmática de duplaface, estando em crise não um, mas dois paradigmas. O primeiro seria o paradigma do modelo liberal-individualista-normativista, enquanto o segundo, o paradigma epistemológico da

\footnotetext{
${ }^{9}$ DWORKIN, Levando os direitos a sério, op. cit, p. 127.

${ }^{10}$ STRECK, Hermenêutica jurídica e $(m)$ crise, op. cit., p. 118.

11 MOTTA, Francisco José Borges. Levando o direito a sério: uma crítica hermenêutica ao protagonismo judicial. 2. ed. rev. e ampl. Porto Alegre: Livraria do Advogado, 2012. p. 75, nota de rodapé n. 187.

12 STRECK, O que é isto, op. cit., p. 13.

${ }^{13}$ STRECK, Hermenêutica jurídica e $(m)$ crise, op. cit., p. 71.
} 
filosofia da consciência. Tal problemática estaria gerando, segundo o referido autor, um Direito alienado da sociedade. ${ }^{14}$

Cabe referir que a denominada crise do modelo liberal-individualista-normativista do direito revela-se na medida em que o direito brasileiro foi desenvolvido de forma a atender tão somente as relações de cunho privado. Isto é, o direito não está preparado para as questões atinentes aos direitos transindividuais. Esta crise de modelo acarretou que institutos importantes como o mandado de injunção e a substituição processual, trazidos pela Constituição Federal de 1988, não fossem aplicados em sua total eficácia, diante da falta de preparo por parte da dogmática jurídica em lidar com institutos que contrariem o modelo individualista.

Ainda no contexto da crise do modelo liberal-individualista-normativista, reside a problemática da não superação do positivismo normativista por parte do Direito brasileiro. Isto se dá em função da má diferenciação entre os conceitos de positivismo exegético (sintático) e positivismo normativista (semântico) por parte da dogmática jurídica. Com isso, o neoconstitucionalismo tornou-se uma espécie de continuação do positivismo. ${ }^{15}$

Deve-se esclarecer tal distinção. Por positivismo exegético, pode-se entender o positivismo primitivo, o qual tinha por característica a separação entre direito e moral, bem como fundava-se na proibição de interpretar. É de referir que esta ideia ainda persiste no imaginário jurídico, haja vista o exposto a respeito da aplicação por subsunção e da desnecessidade de interpretação na clareza da norma. Já o positivismo normativista tem por base a concepção de que não é possível realizar-se um fechamento semântico do direito. Com isso, esta forma do positivismo entendeu a interpretação como um problema menor, delegado aos aplicadores do direito. A preocupação reside, portanto, na questão da validade das normas. $^{16}$

Quanto a isto, Streck entende que Kelsen foi mal interpretado no que tange ao entendimento de que este teria autorizado a discricionariedade interpretativa. O que Kelsen teria afirmado, em sua obra Teoria Pura do Direito, seria que a aplicação da lei como um ato de vontade do juiz seria uma fatalidade. Sendo inevitável, este autor não teria se preocupado em investigar essa questão. Isso não é dizer que o autor recomendou ou mesmo autorizou este agir por parte dos juízes. Não compreendendo corretamente este ponto, teriam os juristas

\footnotetext{
${ }^{14}$ STRECK, Hermenêutica jurídica e(m) crise, op. cit., p. 97.

${ }^{15}$ STRECK, Hermenêutica jurídica e $(m)$ crise, op. cit., p. 69, 78-79.

${ }^{16}$ STRECK, Hermenêutica jurídica e $(m)$ crise, op. cit., p. 48-51
} 
absorvido tal discricionariedade como uma forma de correção do direito, dadas as insuficiências que este apresentaria. ${ }^{17}$

Delineada a crise do modelo liberal-individualista-normativista, passa-se o enfoque à denominada filosofia da consciência. De forma a demonstrar o pensamento metafísico, Streck, ao abordar Platão, exemplifica:

\begin{abstract}
O Sócrates platônico (aparentemente) não rompe inteiramente com Crátilo e nem com Hermógenes, mas defende uma posição que concilia as precedentes. De fato, se os nomes são criados pelo nomoneta (ou onomaturgo de Platão), eles são uma convenção, como pretendiam os sofistas. Mas se existe uma adequação natural entre o nome e a coisa, é porque de alguma forma ambos participam de um referencial comum, tese defendida por Crátilo. Entre os dois polos (Crátilo e Hermógenes), deliberadamente postos no diálogo para propiciar a apresentação de uma tese intermediária, Platão começa a esconder o ser, ao trabalhar com a concepção de que é possível saber o que seja a coisa sem o uso da linguagem. Segundo a tese platônica, a palavra é tomada como representação da coisa. Quando o nomoneta ou o onomaturgo (dador de nomes) estabelece os nomes para as coisas, ele não o faz segundo sua própria vontade, mas segundo um modelo ideal (inato) ao qual ele não tem acesso direto, e que orienta, de alguma maneira, suas escolhas. (grifo do autor $)^{18}$
\end{abstract}

Observa-se que, no trecho supracitado, Platão propõe a possibilidade de compreensão dos objetos sem o uso da linguagem. A linguagem, assim, seria mero instrumento para representar a coisa, a qual seria acessível diretamente, sem necessidade de intermediação. A mudança paradigmática evidenciada pela alteração terminológica (de metafísica para ontologia) consiste na alteração do esquema sujeito-objeto para um esquema que privilegia a relação sujeito-sujeito. É nisto que consiste o giro ontológico-linguístico (linguistic turn). Conforme indicado acima, o pensamento filosófico se desenvolve no sentido de deixar de acreditar na existência de uma essência para as coisas. O acesso não se dá de forma direta aos objetos, não sendo possível extrair destes a essência. Pelo contrário, entende-se, como citado anteriormente, que o mundo só pode ser entendido, só é revelado na e pela linguagem, isto é, através da linguagem.

Segundo Streck, este paradigma, denominado filosofia da consciência, acaba por ser rompido pelo linguistic turn, caracterizado pelo ingresso do mundo prático na filosofia:

Pode-se afirmar que, no linguistic turn, a invasão que a linguagem promove no campo da filosofia transfere o próprio conhecimento para o âmbito da linguagem, onde o mundo se descortina; é na linguagem que se dá a ação; é na linguagem que se dá o sentido (e não na consciência de si do pensamento pensante). O sujeito surge na linguagem e pela linguagem, a partir do que se pode dizer que o que morre é a

\footnotetext{
${ }^{17}$ STRECK, Hermenêutica jurídica e(m) crise, op. cit., p. 77.

${ }^{18}$ STRECK, Hermenêutica jurídica e(m) crise, op. cit., p. 154.
} 
subjetividade "assujeitadora", e não o sujeito da relação de objetos. (grifo do autor $)^{19}$

O autor sintetiza esta questão dizendo que “a viragem ontológico-linguística é o raiar da nova possibilidade de constituição do sentido". ${ }^{20}$ Ocorre que o sentido passa a ser constituído através de uma construção linguística, argumentativa. Há uma atribuição de sentido por parte do intérprete. A verdade ou inverdade não mais é verificável em comparação com a realidade presente na essência do objeto. No contexto da filosofia da linguagem, o importante não é propriamente o objeto em si mesmo considerado, mas o que se diz a respeito deste objeto. ${ }^{21}$ Desta forma, é através da linguagem que se possibilita o acesso ao objeto. A linguagem é, portanto, condição de possibilidade.

É possível apontar dois tipos de manifestação do paradigma da filosofia da consciência, também chamado de paradigma da subjetividade. O primeiro seria explícito, quando se assume que o ato de julgar reflete um ato de vontade, bem como quando, mesmo de maneira implícita, baseiam-se em uma interpretação individual (solipsista). O segundo seria composto por adeptos das teorias da argumentação jurídica, a exemplo de Habermas e Alexy, já que tais teorias, para Streck, não deixam de ser dependentes da discricionariedade judicial. $^{22}$

Ainda no contexto da crise de paradigmas ora delineada, considera-se que a sua persistência no âmbito jurídico guarda intima relação com aquilo que Luis Alberto Warat denomina de senso comum teórico dos juristas. Segundo o autor, este conceito refere-se às “condições implícitas de produção, circulação e consumo das verdades nas diferentes práticas de enunciação e escritura do Direito.”23, sendo caracterizado pela reprodução de valores através da atribuição de sentidos não explicados pelos operadores do direito. ${ }^{24}$ Isto é, no meio jurídico são propagadas teses e doutrinas sem adequada fundamentação teórica, as quais são reproduzidas sem o devido filtro crítico por parte da comunidade jurídica.

Complementando sua crítica, Streck indaga: “a pergunta que se opõe é: onde ficam a tradição, a coerência e a integridade do Direito? Cada decisão parte (ou estabelece) 'um grau zero de sentido’?”. ${ }^{25}$ Tal questionamento procura demonstrar a ausência de superação do

\footnotetext{
${ }^{19}$ STRECK, O que é isto, op. cit., p. 14-15.

${ }^{20}$ STRECK, O que é isto, op. cit., p. 16.

${ }^{21}$ STRECK, Hermenêutica jurídica e $(m)$ crise, op. cit., p. 71.

22 STRECK, O que é isto, op. cit., p. 23-24

${ }^{23}$ WARAT, Luis Alberto. Introdução geral ao direito I - Interpretação da lei: temas para uma reformulação. Porto Alegre: Fabris, 1994. p. 13.

${ }^{24}$ STRECK, Hermenêutica jurídica e $(m)$ crise, op. cit., p. 83-84.

${ }^{25}$ STRECK, O que é isto, op. cit., p. 27.
} 
paradigma da filosofia da consciência, onde Direito e sociedade estão à disposição das convicções individuais de cada julgador, muitas vezes na contramão do que foi democraticamente produzido - validamente referendado pela Constituição.

\section{AS CONTRIBUIÇÕES DE HEIDEGGER E GADAMER}

De forma a concretizar a noção de que a Hermenêutica Filosófica ${ }^{26}$ é especialmente relevante para a interpretação e aplicação do Direito, importante abordar os pensamentos dos filósofos Martin Heidegger e Hans-Georg Gadamer, os quais contribuíram sobremaneira para a ruptura do paradigma da filosofia da consciência e propuseram uma nova forma de pensar as ciências do espírito, a partir da já referida centralidade da linguagem.

Para romper com o esquema sujeito-objeto, Heidegger propõe em sua principal obra, intitulada Ser e tempo, aquilo que chama de uma ontologia fundamental. Fundamental não no sentido de uma superontologia, como aclarado por Casanova, mas como uma forma de questionar a possibilidade de ser desenvolvida uma ontologia, um estudo acerca do ser. Esta ontologia fundamental heideggeriana teria, por sua vez, três subprojetos: a destruição da história da ontologia, o desenvolvimento de uma hermenêutica da faticidade e o desenvolvimento de uma analítica existencial. ${ }^{27}$

Segundo Casanova, "Ser e tempo inicia-se, em outras palavras, com a constatação de que o problema central de toda ontologia, o significado daquilo que é, do ser, do ser do ente, não foi resolvido no interior da história da ontologia.” ${ }^{28}$ Destarte, Heidegger aborda três conceitos interdependentes, quais sejam: ser, ente e Dasein. A respeito do conceito de ser, Heidegger afirma sua complexa determinação, nas palavras que seguem:

\footnotetext{
No solo da arrancada grega para interpretar o ser, formou-se um dogma que não apenas declara supérflua a questão sobre o sentido do ser como lhe sanciona a falta. Pois se diz: "ser" é o conceito mais universal e o mais vazio. Como tal, resiste a toda tentativa de definição. Esse conceito mais universal e, por isso, indefinível prescinde de definição. Todo mundo o emprega constantemente e também compreende o que ele, cada vez, pretende designar. (grifo meu) ${ }^{29}$
}

\footnotetext{
${ }^{26}$ Importante observar que Heidegger e Gadamer optam por denominações diferentes para abordar a questão hermenêutica. Enquanto Heidegger a utiliza a expressão Filosofia Hermenêutica, Gadamer prefere a expressão Hermenêutica Filosófica, por considerar haverem diferenças entre seu pensamento e o de Heidegger. Para efeitos deste trabalho, adota-se a expressão Hermenêutica Filosófica por considerar-se que Gadamer vem para aprofundar a filosofia desenvolvida por Heidegger, agregando a ela a importante noção de tradição.

${ }^{27}$ CASANOVA, Marco Antônio. Compreender Heidegger. Petrópolis, RJ: Vozes, 2009. p. 79

${ }^{28}$ Ibidem, p. 76

${ }^{29}$ HEIDEGGER, Martin. Ser e tempo. Volume I. Tradução de Márcia de Sá Cavalcante. 4 ed. Petrópolis: Vozes, 1993. p. 27.
} 
Observa-se que Heidegger, neste ponto, contorna a questão da conceituação do ser, alegando ser este indefinível. Contudo, o próprio autor faz uma ressalva: “a impossibilidade de definir o ser não dispensa a questão de seu sentido, ao contrário, justamente por isso a exige”. ${ }^{30}$ Assim, o objeto de estudo não é propriamente a conceituação do ser, mas seu sentido a cada momento. A temporalidade, pois, "possibilita o projeto do Dasein como questionador do ser.” Daí intitular-se a obra Ser e tempo. ${ }^{31}$

A ideia do ente é, por sua vez, decorrente na noção de ser, sendo que ambos os conceitos são complementares. Heidegger aponta que "o ser é sempre o ser de um ente". ${ }^{32}$ Pode-se, a partir disso, referir que o ser tem uma relação de caráter indissociável com o ente, como se aquele estivesse neste contido. Heidegger prossegue, relatando que "o que resulta como interrogado na questão do ser é o próprio ente” (grifo do autor). Conclui ao afirmar que ente é "tudo de que falamos, tudo que entendemos, com que nos comportamos dessa ou daquela maneira, ente é também o que e como nós mesmos somos”. ${ }^{33}$

Para Zimmerman, "Dasein significa o local onde o ser ocorre". ${ }^{34}$ Este termo é traduzível pelas expressões ser-aí ou pre-sença. A respeito disto, Casanova afirma:

\begin{abstract}
O termo "ser-aí" designa em um primeiro momento simplesmente o ser do homem. No entanto, ele não se mostra apenas como mais uma definição que irá incontornavelmente se juntar ao longo rol das definições cunhadas no interior da história do pensamento ocidental. Quase como se pudéssemos dizer: ser-aí é o conceito heideggeriano de homem. Não, não e mais um não! O emprego do termo ser-aí indica no presente contexto uma transformação radical do modo mesmo de pensar o ser do homem. Antes de mais nada, é preciso ter em vista o fato de ser-aí não ser um termo cunhado por Heidegger a partir da pergunta: o que é o homem? O termo ser-aí inviabiliza desde o princípio a colocação de uma tal pergunta, na medida em que possui um modo de ser que o distingue fundamentalmente de todos os entes marcados pela presença de propriedades quididativas. ${ }^{35}$
\end{abstract}

O referido autor afirma ainda que o Dasein seria um ente em "princípio absorvido na facticidade incontornável de seu mundo, ao mesmo tempo em que seja marcado por uma relação originária e indissolúvel com o ser.”. ${ }^{36}$ Cabe frisar que o "ser-aí” ocupará, no âmbito do giro, o lugar outrora pertencente ao sujeito da relação sujeito-objeto. Desta forma, o sujeito

\footnotetext{
${ }^{30}$ HEIDEGGER, Ser e tempo I, op. cit., p. 29.

31 SER E TEMPO. In: HUISMAN, Denis. DICIONÁRIO de obras filosóficas. Tradução de Ivone Castilho Benedetti. São Paulo: Martins Fontes, 2000, p. 497-499.

${ }^{32}$ HEIDEGGER, Ser e tempo I, op. cit., p. 35.

${ }^{33}$ HEIDEGGER, Ser e tempo I, op. cit., p. 32.

${ }^{34}$ ZIMMERMAN, Michael E. apud STRECK, Hermenêutica juridical e(m) crise, op. cit., p. 251.

${ }^{35}$ CASANOVA, Compreender Heidegger, op. cit., p. 89.

${ }^{36}$ CASANOVA, Compreender Heidegger, op. cit., p. 86-87.
} 
deixa de ser um observador descontextualizado e capaz de acessar diretamente o objeto de análise, passando a chamar-se Dasein. Este está, pois, inserido na faticidade do mundo, sendo partícipe de uma relação sujeito-sujeito, realizada na e pela linguagem, através da qual tem acesso ao mundo.

Heidegger, com a obra Hermenêutica da Faticidade, altera o objeto da hermenêutica, a qual deixa de ter como objeto exclusivo a interpretação textual, passando a incluir a faticidade. A respeito da faticidade, pode-se dizer que esta representa, para o ser-aí, o passado, sendo o selo histórico nele imprimido, enquanto o futuro seria um ter-que-ser que caracteriza seu modo-de-ser. ${ }^{37}$. Com isso, percebe-se que a faticidade é um importante elemento do processo de compreensão do ser inserido no Dasein (ser-aí). Esta compreensão ocorre inserida na faticidade do mundo, sofrendo as influências do mundo prático.

No entender de Heidegger, a superação da metafísica (e o ingresso no paradigma da linguagem) dá-se a partir da não entificação do ser, visto que este não pode ser confundido com o ente, no que Streck pontua que:

A diferença ontológica é o suporte do ser e do ente. No ente é pensado e dito o ser. O ente não existe como ente, ou seja, o ente não existe - no sentido de sua existência - sem estar junto ao ser (o ente só é no seu ser e o ser é sempre ser-em, ser-junto (Sein-bei). ${ }^{38}$

Falar em diferença ontológica é dizer justamente que ser e ente não são conceitos completamente distintos. Se o fossem, o ser seria um novo ente, e tal diferença seria simplesmente ôntica (entre entes) e não ontológica (entre ser e ente). Como será abordado na sequência, um exemplo de diferença ontológica é a diferença entre texto (ente) e norma (ser), visto que a todo o texto se atribui uma norma. Pode-se dizer que tal diferença "consiste na transcendência do ser-aí, ou seja, no seu confronto com o ser mediante a compreensão deste". ${ }^{9}$ Para Stein, esta diferenciação é, “ao lado do círculo hermenêutico, um dos dois teoremas fundamentais heideggerianos para superar a metafísica”. ${ }^{40}$

Tendo-se claro, portanto, que o ser não é o ente, deve-se ter ainda em vista que o Dasein é um ente em interação com o mundo, o qual tem uma estrutura simbólica, sendo que,

\footnotetext{
${ }^{37}$ STRECK, Hermenêutica jurídica e(m) crise, op. cit., p. 239.

${ }^{38}$ STRECK, Hermenêutica jurídica e (m) crise, op. cit., p. 260.

${ }^{39}$ DIFERENÇA ONTOLÓGICA. In: ABBAGNO, DICIONÁRIO de filosofia, op. cit., p. 276.

${ }^{40}$ STEIN apud STRECK, Hermenêutica jurídica e $(m)$ crise, op. cit., p. 258-259.
} 
para Heidegger, o modo de ser do Dasein é a compreensão. Compreensão esta que se dá no Dasein de forma pré-ontológica. ${ }^{41}$

Ernildo Stein, ao abordar as teses centrais da obra Ser e tempo, afirma que uma destas, ao focar-se na clarificação da questão do ser, concluiria que tal esclarecimento somente se daria a partir do recurso ao Dasein, uma vez que este, o homem, seria o único ente capaz de efetivamente compreender o ser. ${ }^{42}$

Para Heidegger, "toda interpretação que se coloca no movimento de compreender já deve ter compreendido o que se quer interpretar." 43 Isto é, “no Dasein reside uma précompreensão" 44 , referida por Stein como sendo uma maneira de "ver a compreensão como uma estrutura antecipadora”. ${ }^{45}$ Streck complementa ao afirmar que este sentido articulado pela interpretação é aquele já entendido como uma possibilidade no momento da compreensão. Na abertura da compreensão, o sentido é, portanto, aquele que tem a possibilidade de ser articulado. ${ }^{46}$ Nas palavras de Heidegger:

\begin{abstract}
A interpretação de algo como algo funda-se, essencialmente, numa posição prévia, visão prévia, e concepção prévia. A interpretação nunca é apreensão de um dado preliminar, isenta de pressuposições. Se a concreção da interpretação, no sentido da interpretação textual exata, se compraz em se basear nisso que "está" no texto, aquilo que, de imediato, apresenta como estando no texto nada mais é do que a opinião prévia, indiscutida e supostamente evidente, do intérprete. Em todo princípio de interpretação, ela se apresenta como sendo aquilo que a interpretação necessariamente já “põe”, ou seja, que é preliminarmente dado na posição prévia, visão prévia e concepção prévia. ${ }^{47}$
\end{abstract}

Esta compreensão, para Stein, nunca se dará de forma pura. Isso porque a compreensão sempre estará ligada ao modo-de-ser no mundo do Dasein, à sua faticidade, conforme já abordado. Para o autor, é neste ponto que se situa o núcleo do processo hermenêutico heideggeriano. ${ }^{48}$ Cabe aqui retomar que o pensamento heideggeriano se funda no rompimento da estrutura sujeito-objeto. Desta forma, a compreensão do Dasein ocorre através da linguagem, sendo esta condição de possibilidade para a compreensão. Isto é aclarado por Streck da seguinte forma:

\footnotetext{
${ }^{41}$ STRECK, Hermenêutica jurídica e(m) crise, op. cit., p. 249-251.

42 STEIN, Ernildo. Seis estudos sobre ser e tempo. 2. ed. Petrópolis: Vozes, 1990, p. 11.

${ }^{43}$ HEIDEGGER, Ser e tempo I, op. cit., p. 209.

${ }^{44}$ STRECK, Hermenêutica jurídica e $(m)$ crise, op. cit., p. 252.

45 STEIN, Ernildo. Aproximações sobre hermenêutica. Porto Alegre: Edipucrs, 1996, p. 59.

${ }^{46}$ STRECK, Hermenêutica jurídica e $(m)$ crise, op. cit., p. 252.

${ }^{47}$ HEIDEGGER, Ser e tempo I, op. cit., p. 207.

${ }^{48}$ STEIN, Aproximações sobre hermenêutica, op. cit., p. 61.
} 
A linguagem, então, é totalidade; é abertura para o mundo; é, enfim, condição de possibilidade. Melhor dizendo, a linguagem, mais do que condição de possibilidade, é constituinte e constituidora do saber, e, portanto, do nosso modo-de-ser-no-mundo, que implica as condições de possibilidades que temos para compreender e agir. Isso porque é pela linguagem e somente por ela que podemos ter um mundo e chegar nesse mundo. Sem linguagem não há mundo, enquanto mundo. (grifo do autor) ${ }^{49}$

Tal informação é complementada por Stein ao afirmar que é apenas através da linguagem que se dará o acesso aos objetos. ${ }^{50}$ Estes, por sua vez, não são os objetos puramente considerados, a exemplo do que se dava com a noção de mundo das ideias de Sócrates. Os objetos são, assim, considerados enquanto algo. São analisados, portanto, de forma contextualizada.

Partindo do filosofar de Heidegger, Gadamer virá a afirmar que "ser que pode ser compreendido é linguagem”. ${ }^{51}$ Para Stein, este enunciado é o de maior importância na obra de Gadamer, salientando que

isso que ele diz no fim do livro, “ser que pode ser compreendido é linguagem”, já está pressuposto desde o começo porque desenvolve a ideia de que estamos envolvidos na linguagem, da qual determinamos a verdade ou a falsidade das proposições. Existe, portanto, uma experiência da linguagem, de que a linguagem é mais do que nós mesmos, na medida em que a linguagem é parte daquilo em que estamos enraizados, e é parte de nossa faticidade. (grifo do autor) ${ }^{52}$

Chris Lawn equipara a importância deste enunciado ao seguinte dizer de Heidegger: “A linguagem é a casa do ser”53. Para este autor, embora a questão da linguagem pareça supérflua em um primeiro momento, visto que esta teria o simples objetivo de comunicar, a questão se configura de maneira mais complexa. Ocorre que, conforme este indica, o que Gadamer pretende com este enunciado é demonstrar que, mesmo que existam linguagens e sentimentos não verbais, como a música, a arte e a própria dor, não existe nada que, após compreendido, não possa ser expresso através da palavra. ${ }^{54}$

Gadamer, como Heidegger, trabalha com a noção de pré-compreensão antecipadora do sentido. Esta pré-compreensão dá-se a partir dos chamados preconceitos, termo utilizado pelo filósofo sem sua carga semântica negativa, para significar as concepções prévias do intérprete

\footnotetext{
${ }^{49}$ STRECK, Hermenêutica jurídica e(m) crise op. cit., p. 254-255.

${ }^{50}$ STEIN, Aproximações sobre hermenêutica, op. cit., p. 60.

${ }^{51}$ GADAMER apud STEIN, Aproximações sobre hermenêutica, op. cit., p. 73.

52 STEIN, Aproximações sobre hermenêutica, op. cit., p. 73.

${ }^{53}$ HEIDEGGER apud LAWN, Cris. Compreender Gadamer. Tradução de Hélio Magri Filho. 2. ed. Petrópolis, RJ: Vozes, 2010, p. 111.

${ }^{54}$ LAWN, Compreender Gadamer, op. cit., p. 111-115.
} 
ao acessar o texto. Estas concepções podem ser, por sua vez, valorizadas tanto positiva quanto negativamente. ${ }^{55}$ A este respeito, para o filósofo:

\begin{abstract}
Quem quiser compreender um texto realiza sempre um projetar. Tão logo apareça um primeiro sentido no texto, o intérprete prelineia um sentido do todo. Naturalmente que o sentido apenas se manifesta porque quem lê o texto lê a partir de determinadas expectativas e na perspectiva de um sentido determinado. A compreensão do que está posto no texto consiste precisamente na elaboração desse projeto prévio, que, obviamente, tem que ir sendo constantemente revisado com base no que se dá conforme se avança na penetração do sentido. (grifo meu) ${ }^{56}$
\end{abstract}

Existe, pois, a possibilidade de o intérprete calcar-se em falsos preconceitos, os quais acabam por gerar uma compreensão equivocada. Apenas com base nos pré-juízos verdadeiros é construída a compreensão. Fazer esta distinção exige a aliança entre uma consciência formada hermeneuticamente e uma consciência histórica. Ter consciência dos próprios préjuízos implica, por sua vez, em sua suspensão. Conforme Streck, "na medida em que um préjuízo nos determina, não o conhecemos nem o pensamos como um juízo”. Isto é, apenas é possível visualizar um preconceito como tal no momento em que este é suspenso. Esta suspensão é possível através do encontro do intérprete com a tradição, conceito que será explicitado na sequência. ${ }^{57}$

A pré-compreensão identifica-se com a noção de círculo hermenêutico, na medida em que, ao acessar o texto, o intérprete já está situado no horizonte de sentido que este lhe abre. ${ }^{58}$ Falar em círculo hermenêutico é abordar o caráter circular da compreensão, visto que o homem (Dasein) apenas compreende a si mesmo ao compreender o ser, embora necessite já compreender-se para compreendê-lo. ${ }^{59} \mathrm{Na}$ interpretação, isto quer dizer que esta é revista a todo instante pelo leitor, à medida que este vai se abrindo aos significados que o texto lhe propõe, no que Streck esclarece que,

para Gadamer, aquele que pretende compreender não pode entregar-se desde o princípio à sorte de suas próprias opiniões prévias e ignorar a mais obstinada e consequentemente possível opinião do texto. Aquele que pretende compreender um texto tem que estar em princípio disposto a que o texto lhe diga algo. Uma consciência formada hermeneuticamente tem que se mostrar receptiva desde o início para a condição do texto. Entretanto, esta receptividade não pressupõe nem neutralidade nem autocancelamento, senão que inclui uma matizada incorporação das próprias opiniões prévias e pré-juízos. (grifo do autor) ${ }^{60}$

\footnotetext{
${ }^{55}$ GADAMER, Verdade e Método, op. cit., 407.

${ }^{56}$ GADAMER, Verdade e Método, op. cit., p. 402.

${ }^{57}$ STRECK, Hermenêutica jurídica e $(m)$ crise, op. cit., p. 333.

${ }^{58}$ SOARES, Ricardo Maurício Freire. Hermenêutica e interpretação jurídica. São Paulo: Saraiva, 2010, p. 11.

${ }^{59}$ STRECK, Hermenêutica jurídica e(m) crise, op. cit., p. 240.

${ }^{60}$ STRECK, Hermenêutica jurídica e(m) crise, op. cit., p. 263.
} 
Destarte, tem-se que o intérprete dialoga com o texto a partir de suas concepções prévias e é por meio deste diálogo que a compreensão do texto acontece. Como referido, é necessário que o leitor tenha a intenção de deixar que o texto lhe diga alguma coisa, caso contrário não ocorrerá o necessário diálogo entre o horizonte do Dasein e o horizonte histórico, acabando prejudicada a própria compreensão.

Gadamer, segundo Streck, entende que o objeto da pré-compreensão será a tradição, a qual possui uma dimensão linguística, uma vez que é transmitida através da linguagem, primeiramente de maneira verbalizada e posteriormente através da escrita. Prossegue, afirmando que ao compreender-se um fenômeno passado, ocorre o que se chama de uma fusão de horizontes, sendo a presença de um horizonte histórico condição de possibilidade para este fenômeno. Este horizonte histórico, por sua vez, será eventualmente superado através desta fusão de horizontes. ${ }^{61}$

Finalmente, conclui-se a abordagem ao pensamento gadameriano retomando-se a questão, já apontada no início deste artigo, da impossibilidade da compreensão sem aplicação. No entender de Gadamer, “a tarefa da interpretação consiste em concretizar a lei em cada caso, isto é, em sua aplicação”, 62 Não é possível, como se realizava na hermenêutica clássica, interpretar por partes (subtilitas intelligendi, subtilitas explicandi, subtilitas applicandi). Todos os momentos da interpretação concebidos pelas concepções clássicas da hermenêutica ocorrem em um momento único, chamado por Gadamer de applicatio, ${ }^{63}$ indicando Streck que:

\begin{abstract}
Negar que a norma é produto da interpretação do texto e que interpretar é sempre um ato aplicativo (applicatio), implica negar a temporalidade. Os sentidos são temporais. A diferença (que é ontológica) entre texto e norma ocorre na incidência do tempo. Daí a impossibilidade de reprodução de sentidos, como se o sentido fosse algo que pudesse ser arrancado dos textos (da lei, etc.). [...] O texto será sempre "já normado" pelo intérprete. É por isso que um mesmo texto dá azo a várias normas. A norma será sempre, assim, resultado de um processo de atribuição de sentido (Sinngebung) a um texto. (grifo do autor) ${ }^{64}$
\end{abstract}

Prossegue, afirmando que o simples ato de acessar um texto, de lê-lo, já gera a atribuição de um sentido. Neste caso, de uma norma ao texto. Isto se dá, conforme aludido neste capítulo, dentro do círculo hermenêutico e em função do fenômeno da pré-compreensão

\footnotetext{
${ }^{61}$ STRECK, Hermenêutica jurídica e(m) crise, op. cit., p. 265-266.

${ }^{62}$ GADAMER, Verdade e Método, op. cit., p. 489.

${ }^{63}$ STRECK, Hermenêutica jurídica e(m) crise, op. cit., p. 271-272.

${ }^{64}$ STRECK, Hermenêutica jurídica e (m) crise, op. cit., p. 357.
} 
antecipadora do sentido do texto. Por este processo, o intérprete já delineia o sentido do texto no momento de sua leitura, tomando por base seus pré-juízos, seus preconceitos e, em última análise, a tradição. Em seguida (mas no mesmo momento, já que a interpretação não se dá por etapas), da fusão de horizontes realizada entre a sua pré-compreensão baseada na tradição e o horizonte de sentido do texto exsurge a norma presente naquele texto. ${ }^{65}$

Destarte, texto e norma possuem uma diferença ontológica, da mesma forma que se dá a diferenciação entre ser e ente. Não há, pois, uma cisão entre texto e norma. Estes não se constituem em entes distintos. Da mesma maneira que todo ser é um ser de um ente, todo texto contém, ou melhor, a todo texto é atribuível uma norma através da applicatio. Tem-se, portanto que a "norma é, assim, o texto aplicado/concretizado." 66

\section{HERMENÊUTICA E JURISDIÇÃO CONSTITUCIONAL}

Expostas estas considerações a respeito do filosofar de Gadamer e Heidegger, passa-se a investigar até que ponto a Hermenêutica Filosófica vem se inserindo no contexto das decisões do Supremo Tribunal Federal. Neste intuito, oportuno trazer à baila a seguinte afirmação de Streck:

\footnotetext{
Vê-se, pois, que qualquer resposta correta é necessariamente uma resposta adequada à Constituição. Uma norma - que é sempre o produto da interpretação de um texto (que, por sua vez, é sempre evento) - somente é válida se estiver de acordo com a Constituição. Portanto, o intérprete deve, antes de tudo, compatibilizar a norma com a Constituição, conferindo-lhe a totalidade eficacial. (...) Por isso, todo ato interpretativo (portanto, aplicativo) é ato de jurisdição constitucional. Mesmo quando o problema parece estar resolvido mediante a aplicação da regra, deve o intérprete - e se trata de um dever constitucional que tem a sua dimensão dita pelo nível de seus pré-juízos legítimos (ou ilegítimos) - verificar se o princípio que subjaz à regra não aponta em outra direção. (grifo do autor) (grifo meu ${ }^{67}$
}

O objetivo desta investigação se coaduna com o enunciado supracitado. Busca-se verificar a existência de julgados que contenham uma preocupação hermenêutica na hora de interpretar. Através de pesquisa no banco de dados do website do STF (www.stf.jus.br), tanto na parte de pesquisa de jurisprudência como no setor “Constituição e o Supremo”, foram inseridos termos como: "Gadamer”, “Heidegger”, "hermenêutica”, "Hermenêutica Filosófica”, "hermenêutica jurídica”, etc.

\footnotetext{
${ }^{65}$ STRECK, Hermenêutica jurídica e $(m)$ crise, p. 357.

${ }^{66}$ STRECK, Hermenêutica jurídica e $(m)$ crise, op. cit., p. 361.

${ }^{67}$ STRECK, Verdade e consenso: constituição, hermenêutica e teorias discursivas. 4. ed. São Paulo: Saraiva, 2012, p. 314-315.
} 
Aponta-se, desde logo, que a tarefa de buscar nos julgados do STF referências à Hermenêutica Filosófica não foi tarefa simples. A pesquisa do termo “Gadamer” resultou apenas em dois julgados que referiam este autor na seção da doutrina, sendo um destes a Arguição de Descumprimento de Preceito Fundamental nº 46, de 2009, relatada pelo Ministro Eros Grau, e o outro o Recurso Extraordinário no 197917, de 2002, relatada pelo Ministro Maurício Corrêa. Além disso, a pesquisa pela expressão "Hermenêutica Filosófica” também obteve como resultado a ADPF n ${ }^{\circ} 46$, uma vez que o título do livro de Gadamer presente nas referências do julgado continha a expressão.

Por outro lado, a pesquisa pelo autor Heidegger não logrou resultado algum. Como forma de comparação, realizou-se a busca pelo autor Robert Alexy, sendo encontrados 36 acórdãos, 04 decisões monocráticas, 10 decisões da presidência, além de 05 informativos referindo o autor.

A partir destes dados, é possível avaliar, ao menos de forma preliminar, que o autor Robert Alexy possui muito mais inserção no âmbito do Supremo do que os autores enfocados neste artigo. Isso demonstra, pelo menos em parte, que as teses defendidas por estes não foram, atém o momento, acolhidas pelo tribunal constitucional brasileiro.

$\mathrm{Na}$ pesquisa pelo termo "hermenêutica", todavia, foi possível encontrar mais resultados positivos. Foram localizados 139 acórdãos, 330 decisões monocráticas, 9 decisões da presidência, 2 questões de ordem e 38 informativos com referência ao termo. A questão que se levanta, contudo, é de que este vocábulo é demasiadamente genérico, sendo por vezes utilizado como sinônimo do termo interpretação. Logo, a pesquisa não possui a capacidade de demonstrar, sem a análise detida de cada resultado, se estes indicam efetivamente que os julgados em tela abordem a questão da Hermenêutica Filosófica.

Já a procura pela expressão "hermenêutica jurídica” resultou em interessante julgado, o qual estava localizado no setor de informativo de jurisprudência. Trata-se de Agravo Regimental no Habeas Corpus $n^{0} 84486 / \mathrm{SP}^{68}$, relatado pelo Ministro Celso de Mello. No acórdão, encontra-se uma referência ao termo hermenêutica jurídica, em uma citação, realizada pelo Min. Celso de Mello, do autor José Frederico Marques, a qual consiste no seguinte:

“O sentido da cláusula constitucional inerente à soberania dos veredictos do Júri não se confunde, em nosso direito positivo, com a noção de absoluta irrecorribilidade das decisões proferidas pelo Conselho de Sentença. Bem o demonstrou, já na

\footnotetext{
${ }^{68}$ BRASIL, Supremo Tribunal Federal. Habeas Corpus no 84486 AgR / SP (01/06/2010). Disponível em:
} <http://redir.stf.jus.br/paginadorpub/paginador.jsp?docTP=AC\&docID=612986> Acesso em: 29 mar. 2012. 
vigência da Constituição de 1946 - que igualmente consagrara, de modo explícito, essa prerrogativa institucional do Júri — o saudoso JOSÉ FREDERICO MARQUES (“A Instituição do Júri”, vol. I, p. 40/41, item n. 3, 1963, Saraiva): ‘Tal exegese, além de condenada pela hermenêutica jurídica, tem, ao demais, outro ponto fraco: dá ao vocábulo soberania o sentido absoluto e rígido de poder sem contraste e supremo. (grifo meu) ${ }^{69}$

Embora o autor citado pelo Min. Celso de Mello utilize de forma genérica a expressão "hermenêutica jurídica”, percebe-se, através da leitura do julgado, a existência de um resgate da tradição jurídica a respeito da questão em debate, concernente à soberania das decisões do Tribunal do Júri. Através deste resgate, o ministro logrou demonstrar que o dispositivo do Código de Processo Penal atacado foi recepcionado pela Constituição Federal de 1988, não ferindo, portanto, a soberania do júri.

Outro julgado que há de ser citado é o referente ao Habeas Corpus $n^{0} 82.424-2 / \mathrm{RS}^{70}$, conhecido como caso Ellwanger, cujo acordão foi relatado pelo Min. Maurício Corrêa. Neste ponto, cabe referir um trecho da ementa:

HABEAS-CORPUS. PUBLICAÇÃO DE LIVROS: ANTI-SEMITISMO. RACISMO. CRIME IMPRESCRITÍVEL. CONCEITUAÇÃO. ABRANGÊNCIA CONSTITUCIONAL. LIBERDADE DE EXPRESSÃO. LIMITES. ORDEM DENEGADA. (...) 3. Raça humana. Subdivisão. Inexistência. Com a definição e o mapeamento do genoma humano, cientificamente não existem distinções entre os homens, seja pela segmentação da pele, formato dos olhos, altura, pelos ou por quaisquer outras características físicas, visto que todos se qualificam como espécie humana. Não há diferenças biológicas entre os seres humanos. Na essência são todos iguais. (grifo meu)

Nesse, o STF optou, por maioria, pela interpretação do caso a partir da tradição internacional, deixando de lado a tese da ponderação de Robert Alexy. O caso consistiu na publicação de livros de caráter antissemita, sendo o pedido de liberdade pautado no argumento eminentemente semântico de que a discriminação aos judeus não constitui o crime de racismo, visto que este grupo não comporia uma raça propriamente dita. Desta forma, aplicar-se-ia o instituto da prescrição à espécie.

Contudo, o entendimento do tribunal foi diverso, entendendo, a partir do voto do Ministro Maurício Corrêa, pela imprescritibilidade do delito. Em seu voto, alegou o ministro:

A questão, como visto, gira em torno da exegese do termo racismo inscrito na Constituição como sendo crime inafiançável e imprescritível. Creio não se lhe poder

${ }^{69}$ BRASIL, Supremo Tribunal Federal. Habeas Corpus no 84486 AgR / SP (01/06/2010). Disponível em: $<$ http://redir.stf.jus.br/paginadorpub/paginador .jsp?docTP=AC\&docID=612986> Acesso em: 29 mar. 2012.

70 BRASIL, Supremo Tribunal Federal. Habeas Corpus $n^{\circ}$ 82.424-2/RS (17/09/2003) Disponível em: $<$ http://redir.stf.jus.br/paginadorpub/paginador.jsp?docTP=AC\&docID=79052> Acesso em: 29 mar. 2012. 
emprestar isoladamente o significado usual da raça como expressão simplesmente biológica. Deve-se, na verdade, entendê-lo em harmonia com os demais preceitos com ele inter-relacionados, para daí mensurar o alcance de sua correta aplicação constitucional, sobretudo levando-se em conta a pluralidade de conceituações do termo, entendido não só à luz de seu sentido meramente vernacular, mas também do que resulta de sua valoração antropológica e de seus aspectos sociológicos.

Pode-se afirmar que este julgado se coaduna com os pressupostos da Hermenêutica Filosófica. Em seu voto, o Min. Maurício Corrêa, a exemplo do que ocorreu no julgado anteriormente citado, buscou na tradição internacional a solução para o que seria aparentemente um conflito entre os princípios da liberdade de expressão e da proibição do racismo. Acertado o ministro ao entender, conforme descrito na ementa, que não existe aquilo que se convencionou chamar de raças, visto que todas as pessoas seriam membros da mesma raça: a raça humana.

Resgatou-se, no caso, a tradição a partir da pré-compreensão do intérprete, cuja mente não é tábula rasa. Vê-se que a história é “a condição prévia para que o ente seja um ser-nomundo”. ${ }^{71}$ É notória a discriminação sofrida pelo povo judaico durante o período nazista, não sendo possível que se autorize, em um Estado que pretende respeitar os Direitos Humanos, a distorção e até mesmo a negação destes fatos históricos. Ignorar a história da sociedade global seria dar azo à possibilidade de repetição dos equívocos passados.

É por este motivo que assiste razão à Streck ao afirmar que o julgador não possa tomar atitudes solipsistas no momento do julgamento. ${ }^{72}$ O decidir conforme sua própria consciência, ignorando a tradição do Direito, bem como, no caso, a própria história da humanidade, é produzir, como já referido no início deste artigo, um direito alienado da sociedade.

\section{CONSIDERAÇÕES FINAIS}

Este artigo busca evidenciar a relevância da Hermenêutica Filosófica para a interpretação no Direito. Para tanto, mergulhou-se no fenômeno do giro-ontológicolinguístico para demonstrar a centralidade da linguagem para a construção do conhecimento, o qual abriu as portas para a filosofia da linguagem e superação da metafísica clássica. Para tanto, foram abordados alguns conceitos envolvidos nos pensamentos dos filósofos Heidegger e Gadamer, quais sejam as noções de Dasein, pré-compreensão, tradição e círculo hermenêutico.

\footnotetext{
${ }^{71}$ STRECK, Hermenêutica jurídica e(m) crise, op. cit., p. 264.

${ }^{72}$ STRECK, O que é isto, op. cit., p. 33.
} 
Considera-se que as teses desenvolvidas por Heidegger e Gadamer no âmbito da filosofia da linguagem são de grande valia para a compreensão do fenômeno jurídico brasileiro. Defende-se que a Hermenêutica Filosófica constitui-se em um caminho adequado para a interpretação do Direito brasileiro, especialmente no que tange à esfera constitucional.

A partir deste trabalho, é possível considerar a tradição, nos moldes concebidos por Gadamer, como uma alternativa viável e qualificada para que o jurista pense o Direito. Com o resgate da tradição, evita-se que em cada caso se parta do zero, que se construa um pensamento novo totalmente desvinculado das decisões anteriores e da doutrina consolidada no país. Através deste resgate torna-se possível superar o paradigma da filosofia da consciência e o fenômeno do solipsismo judicial.

As teses gadamerianas e heideggerianas possuem aplicabilidade no Direito pátrio, conforme percebido através da análise do Habeas Corpus n 84486/SP e do Habeas Corpus n ${ }^{\circ}$ 82.424-2/RS. No entanto, tais teses possuem inserção limitada no âmbito do Supremo Tribunal Federal, especialmente se comparadas com as teorias da argumentação jurídica. Com isto, entende-se oportuna a busca por uma maior divulgação e difusão dos pressupostos hermenêuticos no âmago jurídico brasileiro, de forma a concretizar a superação da metafísica e a entrada na filosofia da linguagem no contexto jurídico nacional.

\section{REFERÊNCIAS}

ABBAGNO, Nicola. DICIONÁRIO de filosofia. 4. ed. São Paulo: Martins Fontes, 2000.

ALEXY, Robert. Teoria dos direitos fundamentais. Tradução de Virgílio Afonso da Silva. São Paulo: Maheiros, 2008. 669p.

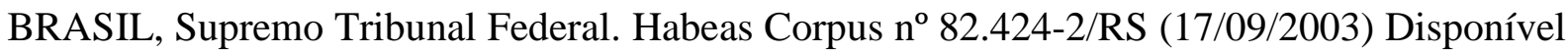
em: <http://redir.stf.jus.br/paginadorpub/paginador.jsp?docTP=AC\&docID= 79052> Acesso em: 29 mar. 2012.

BRASIL, Supremo Tribunal Federal. Habeas Corpus nº 84486 AgR / SP (01/06/2010). Disponível em: <http://redir.stf.jus.br/paginadorpub/paginador.jsp?docTP=AC\&docID= 612986> Acesso em: 29 mar. 2012.

CASANOVA, Marco Antônio. Compreender Heidegger. Petrópolis, RJ: Vozes, 2009. 244p.

DWORKIN, Ronald. Levando os direitos a sério. Tradução de Nelson Boeira. 3. ed. São Paulo: Editora WMF Martins Fontes, 2010. 568p. 
GADAMER, Hans-Georg. Verdade e método: traços fundamentais de uma hermenêutica filosófica. Tradução de Flavio Paulo Meurer. Revisão da tradução de Enio Paulo Giachini. 2. ed. Petrópolis: Vozes, 1998. 731p.

HART, H. L. A. O conceito de direito. Pós-escrito organizado por Penélope A. Bulloch e Joseph Raz. Tradução de Antônio de Oliveira Sette-Câmara; revisão da tradução de Marcalo Brandão Cipolla; revisão técnica Luiz Virgílio Dalla-Rosa. São Paulo: Editora WMF Martins Fontes, 2009.

HEIDEGGER, Martin. Ser e tempo. Volume I. Tradução de Márcia de Sá Cavalcante. 4. ed. Petrópolis: Vozes, 1993. 325p.

HUISMAN, Denis. DICIONÁRIO de obras filosóficas. Tradução de Ivone Castilho Benedetti. São Paulo: Martins Fontes, 2000.

LAWN, Cris. Compreender Gadamer. Tradução de Hélio Magri Filho. 2. ed. Petrópolis, RJ: Vozes, 2010. 208p.

MOTTA, Francisco José Borges. Levando o direito a sério: uma crítica hermenêutica ao protagonismo judicial. 2. ed. rev. e ampl. Porto Alegre: Livraria do Advogado, 2012.

SOARES, Ricardo Maurício Freire. Hermenêutica e interpretação jurídica. São Paulo: Saraiva, 2010.

STEIN, Ernildo. Seis estudos sobre ser e tempo. 2. ed. Petrópolis: Vozes, 1990. 132p.

Aproximações sobre hermenêutica. Porto Alegre: Edipucrs, 1996. 112p.

STRECK, Lenio Luiz. O que é isto - decido conforme minha consciência? 2. ed. rev. e ampl. Porto Alegre: Livraria do Advogado, 2010. 118p.

. Hermenêutica jurídica e $(m)$ crise: uma exploração hermenêutica do Direito. 10. ed. rev. atual. e ampl. Porto Alegre: Livraria do Advogado Editora, 2011. 420p.

Verdade e consenso: constituição, hermenêutica e teorias discursivas. 4. ed. São Paulo: Saraiva, 2012. 639p.

WARAT, Luis Alberto. Introdução geral ao direito I - Interpretação da lei: temas para uma reformulação. Porto Alegre: Fabris, 1994. 